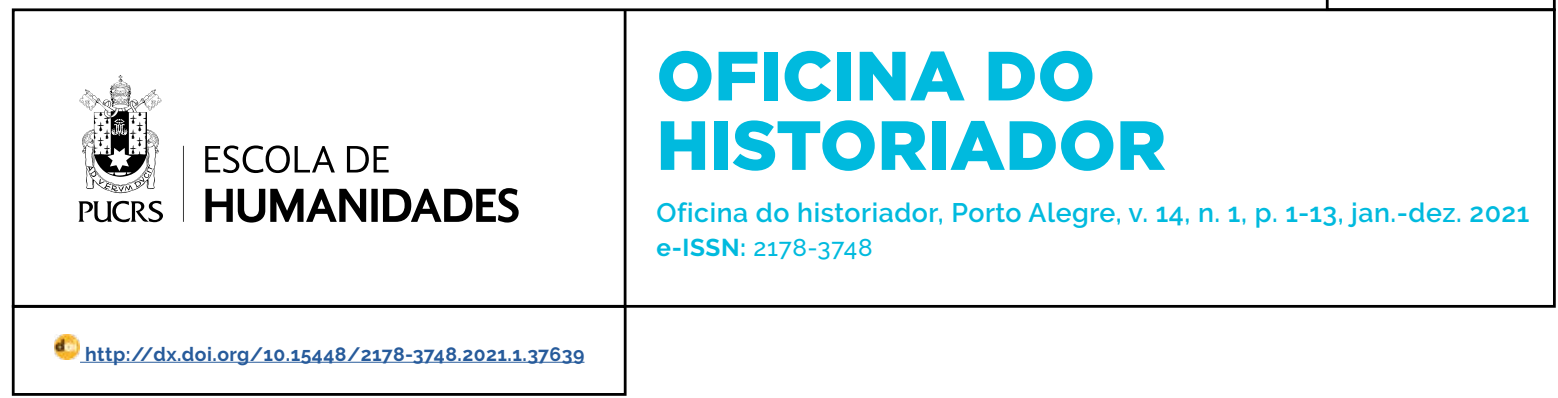

SEÇÃO: ARTIGOS

\title{
An assessment of Christian institutions of care and medicalization in Late Antiquity
}

\author{
Uma análise de instituições de caridade Cristãs e a questão da medicalização \\ durante a Antiguidade Tardia
}

\section{Júlio Matzenbacher \\ Zampietro $^{1}$ \\ orcid.org/0000-0002-2521-4465 \\ juliomzampietro@hotmail.com}

Recebido em: 10 abr.2020 Aprovado em: 29 mai. 2020. Publicado em: 26 abr. 2021.

\section{(c) (i)}

Artigo está licenciado sob forma de uma licença Creative Commons Atribuição 4.0 Internacional.
Abstract: Christian institutions of care, particularly those related to healthcare and the care of the poor, are believed by some scholars to be one of the most important causes for the spread of Christianity in Late Antiquity. However, historiography pertaining to the medicalization of these institutions is scant, and often scholars are at odds with one another regarding key points on the topic. In this article we review the most important positions, as well as give our own take on the topic, through the analysis of written and archaeological evidence. We have found that most of these institutions were not medicalized, and that those that were did not show any clear signs of following traditional ancient medical sects. We conclude that these institutions can mostly be considered important in Christian expansion by their care for, and not by their cure of, of the poor.

Keywords: Late Antiquity. Christianity. Xenodochia.

Resumo: Instituições cristãs de caridade, em particular aquelas relacionadas ao tratamento de doentes e pobres, são vistas por alguns estudiosos como uma das mais importantes causas para a disseminação do Cristianismo durante a Antiguidade Tardia. No entanto, a historiografia sobre o tema da presença ou ausência de médicos nestas instituições é escassa, e muitas vezes seus membros possuem visões muito contrastantes quanto ao tema. Neste artigo, revisamos as posições mais importantes, além de fornecermos nossa própria interpretação do tema, a partir de evidências escritas e arqueológicas. Concluímos que a grande maioria destas instituições não podia contar com médicos, e que aquelas que podiam não nos dão sinal de que estes médicos seguiam alguma das tradições médicas antigas. Concluimos que estas instituições podem ser consideradas importantes para a disseminação do Cristianismo na medida em que cuidavam de pobres, e não que os curavam de doenças.

Palavras-chave: Antiguidade Tardia. Cristianismo. Xenodochia.

\section{Introduction}

Late Antiquity was a transition period for the Roman Empire, particularly so because this was the period in which Christianity first gained hold of the higher echelons of Roman society. In cultural terms, this period was marked by a transition from civic euergetism to a Christian form of philanthropy. The former was a form of public donation by the rich, and could take the form of the construction of public buildings, the performance of public spectacles in Roman arenas, the serving of banquets (VEYNE, 1990, 5-11), or even political favours, if the recipient was another rich Roman. (LENDON, 1997) Examples of this practice can 
be found in the writings of Pliny, the Younger (61 c. 113 CE) (PLINY, Ep., 4.1; 10.8.1), and in the letters of Symmachus (345-402 CE), as well as in other writings of the period. (BROWN, 2012, 93-100; 114-116; ANDO, 2009, 307-308; LENDON, 1997)

Christian philanthropy was different, for it did not base itself on political favours and honour, but on an urge to help the poor. This can be seen in the writings of Saint Athanasius (293 - 373 CE), who criticized members of the Arian sect for not helping the poor (ATHANASIUS, Arian History, LXI), or in the letters of Jerome (347 - $420 \mathrm{CE})$, who compelled people to donate for the poor in some of his letters (JEROME, Ep., LII; LIV), and also posthumously praised those who had done so during their lives. (JEROME, Ep., LXXVII) This came at a time in which the Christian bishop had gained a new social role, as caretaker of the poor. (BROWN, 2002, 26-32)

One particular form of Christian philanthropy, which concerns us here, was the creation of institutions of care, which included houses for orphans, for travellers, for the elderly, and others, all aimed at people who were destitute or at risk of so becoming. (BROWN, 2002, 79) Our objective in the current article is to understand a little better the inner workings of these institutions during this transition period, and particularly of those that seem to have witnessed medical practices within their walls. In the sources, these were termed either xenodocheion (house for travellers), nosokomeion (house for the sick), or ptochotropheion (house for the poor), as well as their Latin variants, all of which seem to have been translated either as hospices or as hospitals in our versions of the extant documents. (VOLTAGGIO, 2011; MILLER, 1997) Therefore, we will not speak of houses for the old or for orphans, for example. This also means that we will not consider monasteries themselves as institutions of care, unless they had facilities that were aimed at treating people from outside the monastery.

The study of these institutions is important because not only can they be seen as embodiments of the Christian ethos, physical landmarks of its expansion, but also because they affected Romans in their daily lives. (HORDEN, 2005. 363-364) Apart from that, there are scholars that argue that Christian philanthropical institutions were of particular importance in the spread of Christianity in Late Antiquity, not only as hallmarks of the general Christian custom of philanthropy but also in more pragmatic ways, by saving more people during great mortality events. (STARK, 1996, 73-94)

Our article is divided into four main sections, followed by a conclusion that summarizes our findings. In the first section, we will briefly outline some ancient medical traditions. In the second section, we will outline the general theories of five modern historians regarding the functioning of these institutions, which includes the presence or absence of physicians and the kinds of medical treatment available to people under care. In the third section we will approach written evidence that speaks of this subject, with simple quantification being applied in order to give more robustness to our analysis. The fourth section will take archaeology into consideration, in order to strengthen or weaken our conclusions from the previous section.

\section{Some ancient medical traditions}

Ancient medicine, especially that related to the Greco-Roman world, presents some complications to its interpretation by modern historians. One of them is the difficulty to create models which include most medical writers considered to pertain to a given current of medical thought and practice. Medical writers often had many contrasting views and drank from very different sources of knowledge, which turns this topic into as complex a matter as any other in historical studies. However, if one takes categories used by the ancients and combines them with modern categories, three main 'sects' can be detected by the time of Galen (129 - 210 CE), which distinguished themselves from one another in the ways they treated patients and in the ways they obtained medical knowledge, as well as in their presuppositions about how medicine should be done.

The first sect is known as the Dogmatists. Medical writers from this sect based their writings 
mainly in the teachings of Hippocrates. These doctors obtained their knowledge mainly from past experience and especially from reasoning (NUTTON, 2004, 194), and in this sense their knowledge is closer to modern medical science than the other sects. Doctors from this sect investigated precisely what caused diseases (NUTTON, 2004, 191), defending the use of dissection and in some cases even vivisection to obtain new knowledge. (JACKSON, 1988, 30-31; FERNGREN, 2009, 20) Galen is the most widely known member of this sect. (NUTTON, 2004, 168)

Methodist medical writers, the second sect, believed that there were a small number of underlying diseases, which could be treated with general methods, a theory which surfaced in adaptation to the sheer size of cities like Rome. (NUTTON, 2004, 187-188) This methodological simplicity led this sect to be seen as born in a society that knew little and cared less about proper medicine (NUTTON, 2004, 187), although in many cases Methodist treatment wasn't so different from that used by members of other sects. (NUTTON, 2004, 187-188) Methodist writers also rejected complex theories and based their diagnostic and treatment in physical symptoms, and not in the theory of humors. (FERNGREN, 2009, 20)

The third sect is that of the empiricists, and as their very name indicates, they searched for past cases comparable in every detail with the patient at hand. They did not invoke any kind of reasoning apart from the search of past cases. (NUTTON, 2004, 191) They avoided the search for hidden causes of diseases (JACKSON, 1988, 30-31; FERNGREN, 2009, 20), for they held the belief that any exercise on dissection modified the structure of the body part under study and was therefore useless for the attainment of new information about its functioning. The only worthwhile practice of anatomical study was, for the Empiricists, the occasional observation of living human beings. (ROCCA, 2016, 354-355)

In addition to these three well-established sects, there was a fourth current of medical writers and practitioners known as pneumatists. They interpreted pneuma, a form of air, to be essential to life in conjunction with the soul (ROCCA, 2016, 349), and gave this pneuma a bigger role in the functioning of the body than the humors of Dogmatists. (JACKSON, 1988, 30-31; JONES-LEWIS, 2016, 396) This is a most diffuse group, for there was never a clearly formed association of people who defended the same Pneumatist ideas. (NUTTON, 2004, 206-207) This characteristic is so strong that some modern historians do not speak of them in their works (FERNGREN, 2009), while others give a quick description of some of their practices without further elaboration. (JACKSON, 1988)

Aside from these three main "schools" of medicine, as well as pneumatism, it is highly likely that there were other lines of thought in medical practice that were not preserved in the written record. (JONES-LEWIS, 2016, 395) Because Dogmatists and their approach to medicine were similar to what modern medicine practices, it is common for their sect to be emphasized by historians in detriment of the others. On the other hand, it was probably the Empiricists who had the upper hand in their time. While their methods were tried and proven, a Dogmatist doctor could easily try to fit his patient into his humor theory, regardless of the observed symptoms, and therefore act based on a wrong diagnosis. (JONES-LEWIS, 2016, 397)

In Late Antiquity, nonetheless, the most common medical theory proposed by our sources is Galenism, a modified version of Galen's Dogmatist theory of the body, present in the writings of Oribasius (c. $320-403$ CE). (ORIBASIUS, 21.1.1-6; 22.29.2) Galen formed his theory through the unification of two different versions of the functioning of the body (ROCCA, 2016, 347-348), which will be approached below. It must be emphasized that other theories of the body existed in Classical times, but these did not have the same repercussion in late antique medical writers. ${ }^{2}$

The first part of Galen's thought is formed by the theory of humors, best known in the form it was

\footnotetext{
2 See, for example, Erasistratus' (304 - 250 BCE) theory of the body being composed by a triple interweaving of arteries, veins, and nerves, discussed by Rocca (2016, 353).
} 
exposed in the Hippocratic Corpus. ${ }^{3}$ According to the author of the Hippocratic treatise On the nature of man, the human body is made of four constituents. These were later known as humors, even though the word is not used in the text. The four humors were phlegm, blood, yellow bile, and black bile. (HIPPOCRATES, On the nature of man, IV) Each of them is associated with a season of the year, in accordance to the characteristics of the season: phlegm, being cold and wet, is dominant during the winter; when the temperature rises during spring it is blood, hot and wet, that starts to predominate; during the summer, a hot and dry season, it is yellow bile that is prevalent; and when autumn comes, with its coldness and dryness, black bile prevails. (HIPPOCRATES, On the nature of man, VII)

An equilibrium of these four humors is the cause of good health, and when this equilibrium was disturbed by heating, cooling, drying, or wetting pain and diseases would ensue. (HIPPOCRATES, On the nature of man, II; IV) According to the author of this Hippocratic treatise, this is why dysenteries and bloody noses are common during the spring. in which blood is prevalent, and also the reason for the vomit of men being made mostly of bile during the autumn. (HIPPOCRATES, On the nature of man, VII-VIII) Except when diseases are acquired through breathing bad air or through the coldness of old age (HIPPOCRATES, On the nature of man, XII), most diseases are caused by regimen, by what people eat. (HIPPOCRATES, On the nature of man, IX) This is also the premise of another Hippocratic treatise, Regimen in health, in which it is stated that "in fixing regimen [one should] pay attention to age, season, habit, land, and physique, and counteract the prevailing heat or cold." (HIPPOCRATES, Regimen in health, II)

Galen's thought is also composed of a second theory, that of the body being composed of four physical elements, namely fire, water, earth, and air. This theory was proposed by Plato in his Timaeus. According to Plato everything physical is composed of these four elements, which includes the human marrow, from which stems the bones, flesh, "and everything of that sort." (PLATO, Timaeus, $73 \mathrm{~b}-\mathrm{c}$ ) Although the marrow is made of the four elements, it must be noticed that flesh and bones do not have air in them. (PLATO, Timaeus, 74a-c)

Apart from these four physical elements, Plato also argued that the body possesses three souls, being one of them divine and the other two mortal. The divine soul is located in the head, while the rest of the body is seen as merely a means to move the head. (PLATO, Timaeus, 44d-45b) The first mortal soul, characterized by passion and courage, is located in the heart, while the second, marked by its appetite, is located beneath the diaphragm, in the same region as the liver, which acts as a deterrent to its impulses. (PLATO, Timaeus, 69d-72d) It is necessary to emphasize that even though Plato's objective with these divisions was to corroborate his theory of the tripartite soul, this line of thought turned itself very influential in later centuries. (ROCCA, 2016, 348)

\section{How Christian hospitals worked}

Before dwelling into the historical evidence for the functioning of the hospital, we find it important to consider different modern theories as to the medicalisation and functioning of these institutions. Having these in mind will let us have a better understanding of how the extant evidence can be used to promote or criticize any of them. For this list we have considered important to mention solely authors that have a more extensive take on the subject, and that don't just mention them in passing. Therefore, Peter Brown's views, for example, are not included here, for even if he does speak of xenodochia he did not express any positioning as to the functioning of these institutions. (BROWN, 2002, 33-35)

\section{III.1. Demetrios Constantelos}

Constantelos' work emphasizes Christian philanthropy and its relationship with institutions of care, be them medicalised or not, that aimed at helping the poor. (CONSTANTELOS, 1968, 68-86)

3 This was a collection of medical treatises which, although attributed to an ancient man named Hippocrates (c.460 - C.370 BCE), is composed of texts from many sources and reflects many medical traditions. See discussion by Jackson (1988, 21) and Jones-Lewis (2016, 387-388). 
Although the author does not focus his research on medicalised institutions, he still states that these kinds of monastic establishments played a role when famines and pestilence plagued the Roman Empire. (CONSTATELOS, 1968, 101) He also included a chapter on hospitals in his work.

Constantelos believed that Christian hospitals during Late Antique and early Byzantine times had no particular medical specialty within them, but showed that the Byzantines had deep knowledge of medicine. Examples include Basil's institution, further approached below, and hospitals built by John Chrysostom in Constantinople. (CONSTANTELOS, 1968, 152156) It was also common for lay Christians to bring the sick and needy either to their homes or to hospitals. (CONSTATELOS, 1968, 159) Apart from the mentioning of one archaeological excavation that might have found a hospital founded by Justinian in Jerusalem (CONSTANTELOS, 1968, 160-162), Constantelos uses only written sources.

\section{II.2. Timothy Miller}

Some decades after Constantelos' work, Timothy Miller published a book on the subject, elaborating on points that Constantelos did not dwell into. Miller's stance on the subject is one that is characterized by some as optimistic. (HORDEN, 2007, 214)

After analysing the evidence, most (if not all) of it literary, he reaches the conclusion that Christian hospitals were centres of medical excellence, that offered the best available treatment for the sick since the $4^{\text {th }}$ century. These institutions started as an outgrowth of Christian philanthropy and were expanded over the centuries, eventually reaching the size and scope of the Pantokrator Xenon in the $12^{\text {th }}$ century, with its dozens of physicians and its specialized care. (MILLER, 1997, xi-xxi)

Miller states that there is an important distinction between Eastern and Western hospitals. While those in the former region can be classified as hospitals if one considers the modern definition of the term, those in the latter could not. Miller justifies his case by emphasizing that Western institutions had little access to physicians, and that they barely cared for nurturing, cleaning, and curing people. These seem to have mostly been houses for strangers. (MILLER, 1997, 5-6)

\section{II.3. Vivian Nutton}

Nutton's take on the working of hospitals was also obtained mainly through written documents. He believes that even if some documents mention the possibility of giving medical treatment to the poor, these institutions were mainly places for the care of strangers, giving them a bed to sleep in, and fresh food and water. Over time, a few of the institutions with physicians went through specializations, and by 640 there were surgeries being performed in at least one of them. (NUTTON, 2013, 314-315)

Nonetheless, one should not seek a purely medical hospital, for caring and curing were inseparable in Late Antiquity. Many of the smaller institutions would have offered only a place to rest and eat, and most writings on these places reflect administrative worries, and not medical matters. (NUTTON, 2013, 315) Therefore, care should take precedence over cure when dealing with these institutions. This view is somewhat different from the one presented by Crislip, which will now be described.

\subsection{Andrew Crislip}

This author is the only one to make more use of archaeological reports on the subject, even if these are still rare, and by their use he reaches new conclusions. Crislip first divides Christian monasticism into two main categories: 1) lavra monasticism, which was marked by its decentralized organization and the absence of physicians; 2) coenobitic monasticism, more centralized and often with the presence of infirmaries in which physicians were to cure sick monastics. (CRISLIP, 2005, 5-7; 9-14)

The second kind of monasticism is credited by Crislip as the originator of the ancient hospital, described by him as having three characteristics: 1) inpatient facilities, for people being treated to have a place to sleep and to eat while they are treated; 2) provision of professional medical care; 3) provision of care out of charity. (CRISLIP, 2005 , 101-102) The difference between the infirmaries of coenobitic monasteries and Christian hospitals is that while the former only offered care for 
monastics, the latter extended its services for the outside community at large. This was a development that first appeared in Basil's institution. (CRISLIP, 2005, 133)

The author considers that even if this is not directly stated in the evidence, it is safe to assume that Basil's institution was home to the performance of medicine in the Greek tradition described in part I. He also states, based on Cassiodorus, that it is certain that this tradition was followed in the Latin West. (CRISLIP, 2005, 35) Crislip also believes that monastics had access to the best medicine of their times (CRISLIP, 2005, 37), and if in lavra monasticism the refusal of treatment was accepted as an ascetic practice, in coenobitic settings monastics were morally obliged to accept this treatment as a form of getting better to continue with monastic duties. (CRISLIP, 2005, 95) From this thoroughly optimistic view, we will now turn to something of a middle ground.

\subsection{Gary Ferngren}

Ferngren's ideas about Christian hospitals are the last ones approached here. He believes that the existence of these institutions made it possible for churches to be able to deal with famines and plagues in an ad hoc basis, and that even if they did not have medical doctors in them the mere giving of food would be enough to cure a majority of the sick. (FERNGREN, 2009, 120-121) The author agrees with Crislip's interpretation of the origins of these institutions from monastery infirmaries, even if he has some criticism of Crislip's general approach. (FERNGREN, 2009, 124-126)

Ferngren believes that even if Christian institutions of care did not have physicians working in them, they could nonetheless offer nonmedical care for those that stayed in them. Even Basil's institution is seen as having a "nonprofessional staff of doctors and medical attendants". (FERNGREN, 2009, 127) He also believes that the care available in these institutions was mainly palliative, and that physicians within monasteries were there by chance, and not in some pre-ordained manner. (FERNGREN, 2009, 115) These were probably overcrowded institutions, given the small number of beds in relation to the number of inhabitants of ancient cities, and only a small portion of them would have had the financial means to employ physicians. (FERNGREN, 2009, 128-130)

In conclusion, there are many different approaches to the matter of the medicalisation and general functioning of Christian institutions of care. What these authors agree on is that at least some of these institutions had physicians working in them, even if for most of them this cannot be said for sure. What they disagree upon is not only in matters of the origins of these institutions, a topic that will not be approached here, but also on the proportion of medicalised institutions in relation to the total number of institutions. While Miller considers that most Christian institutions contained some form of medical care, and Constantelos and Crislip consider that the medicine practiced in them was one of the best available at the time, Nutton and Ferngren disagree with both assessments. We will now turn to our take on the subject.

\section{What the written evidence tells us}

Written evidence is scant on the medicalisation of Christian institutions of care, and particularly so regarding institutions that had physicians working in them. ${ }^{4}$ What follows takes into consideration written evidence that is described in the Appendix 2, located in the end of the report.

The written evidence to which we had access does not permit us to have any substantial conclusions. If medicalisation existed, it seems to have occurred only occasionally, and was not the rule. From the roughly 50 hospitals and institutions for the care of the poor and of travellers mentioned in the evidence under scrutiny, only 5 of these certainly had physicians working in them, as stated by the written evidence. ${ }^{5}$ The results are summarized in the table below.

\footnotetext{
4 A discussion of the prevalence of medicalised hospitals, that does not quantify the available evidence, is done by Horden (2007, 217-218) The appendix contains a full list of all mentions of hospitals. In the table contained in the appendix we also take into consideration sources that leave unclear to how many institutions they are referring - there are four such sources, and here we consider that each one of them adds one institution to the general count. If these are disregarded, the total proportion of institutions that surely had doctors working in them is raised to $10,9 \%$, which does not affect our conclusions.
} 
TABLE 1 - Institutions of care and number of references to physicians.

\begin{tabular}{cccc} 
& Number of institutions & References to physicians & Total \\
\hline $4^{\text {th }}$ Century & 11 & 2 & $18,2 \%$ \\
$5^{\text {th }}$ Century & 6 & 2 & $33,3 \%$ \\
$6^{\text {th }}$ Century & 33 & 1 & $3,0 \%$ \\
Total & 50 & 5 & $10 \%$ \\
\hline
\end{tabular}

Source: Ellaborated by the author

A second point is that most pieces of evidence do not state specifically how many beds were available in each institution. Nonetheless, it is safe to assume, by the pieces of evidence available to us, that these institutions rarely had more than 40 beds available to them, which gives some base for us to agree with Ferngren's assessment of these institutions as overcrowded. (FERNGREN, 2009, 128-130)

None of the pieces of evidence that mention medicalised hospitals furnish us with any guideline as to what kind of medicine was practiced or how many physicians worked in each hospital. On the other hand, there are some written documents of the time that speak of medical practices, in contexts that are not necessarily related to institutions of care but that must nevertheless have had an influence in the practices of these institutions. Here, we will approach five of these documents: the first one is Gregory of Nyssa's On Virginity; the second one is a section of Basil's Long Rules; the third piece of evidence, one of Cassiodorus' Divine Letters; the fourth, a section of Palladius' Lausiac History; the fifth, an excerpt from John of Ephesus'

\section{Lives of the Eastern Saints.}

Gregory of Nyssa had knowledge of Hippocratic medicine, and in particular of the Hippocratic theory of humors. (GREGORY OF NYSSA, On Virginity, XXII) But even if it was a physician who told Gregory of this theory, the author emphasizes only the dietary aspects of it, not once mentioning surgery or any other kind of intervention. Considering Gregory's proximity with the monastic tradition, it is possible to consider this as an evidence for nurturing as the main way of curing the sick in charitable institutions.

The second piece of evidence is contained in Basil of Caesarea's Long Rules. In this document, Basil mentions the three most important aspects of Hippocratic medicine: he indirectly speaks of humors when he states that one should strive for a balance within the body; herbs are directly mentioned as tools for acquiring health when sick; and surgery is mentioned in passing, when Basil states that people even undergo cuts when they seek to be healthy again. (BASIL, Long Rules, 55) If one follows Crislip's theory of the functioning of the Christian hospital, outlined above, one can conclude from Basil's Long Rules that Hippocratic medicine was probably practiced in his complex of institutions of care.

In a later period, and on the other side of the Mediterranean, there is another reference to Hippocratic medicine in relation with Christian monks. In one of his Divine Letters, dating from the mid- $6^{\text {th }}$ century, Cassiodorus tells the people in his monastery that they need to learn medical practices in order to treat the sick more effectively. Although he mentions Hippocrates in this letter, its content does not speak of the theory of humors: emphasis is given to the learning of the use of herbs as medicine. (CASSIODORUS, Divine Letters, 31.1-2) One can conclude from this that if any medicine was practiced in Cassiodorus' monastery, it was not necessarily related to balanced diets or surgery, but possibly only to the use of drugs. A second point is that this document does not speak of institutions of care, that had as their aim to help people outside the monastery - it is a monastic instruction, to be used inside the monastery and probably with the aim of curing solely monks. 
Our fourth piece of evidence is different from the previous ones in the sense that it does not speak of humors or medicine, but of surgery. It is a section of Palladius' Lausiac History that speaks of an ascetic named Stephen, who knew St. Antony and who lived in the shores of Marmarica. This Stephen contracted a cancerous illness and was found by Ammonius and Evagrius while undergoing surgery by a physician. (PALLADIUS, Lausiac History, XXIV.1-2) The excerpt does not make clear that this physician worked at a monastery, or even that the surgery itself was being performed at a monastery. Therefore, it gives us no grounds to link surgeries and monasteries, let alone to Christian institutions of care.

The last piece of evidence to be approached here is a section of John of Ephesus' Lives of the Eastern Saints, in which the author speaks of Abba Aaron, who from an early age decided to pass his days on retreat and religion within a monastery. In thirty years of this life he kept his work towards God, no matter if he was healthy or sick. But after these thirty years he contracted a disease in his loins that led to a gangrene and had to accept the help of physicians. These were able to craft a lead tube to put in the place of his eaten-up loins. (JOHN OF EPHESUS, Lives of the Eastern Saints, 641-645) From this some have concluded that surgeries were commonplace within monasteries (CRISLIP, 2005, 36-38), an interpretation that presents us with two problems: 1) it is not clear whether surgeries were routinely performed by physicians that were members of the monastery, or if physicians from outside the monastery were called whenever an important monastic was sick (and Abba Aaron was undoubtedly one of the most devout monastics, according to John of Ephesus); 2 ) it is not clear if this kind of service was available only to monastics or if it was open to outsiders, a necessary characteristic of Christian philanthropical institutions.

From this outline it is possible to ascertain that any general conclusion obtained from the available written evidence will be tentative. These pieces of evidence are not enough to base generalizations about the workings of Christian philanthropic institutions in the region their authors lived in, and much less about how they functioned in the rest of the Roman Empire. Furthermore, only in the case of Basil can we state with some degree of certainty that institutions of care were related to these medical beliefs, for if Basil knew of Hippocratic medicine it is probable that he would only hire physicians who also did so. It is too bold an affirmation to state that medical practice was generally widespread and followed the Greek tradition of medicine.

In response to this, it might be argued that if physicians were commonly found in these institutions, then it would not make sense to mention them whenever the institutions are mentioned; it would always be implied that they were there. But we seem to have no grounds to assume that this is the case, for it is noteworthy that some sources found it important to emphasize the presence of physicians in some institutions but not in others. Palladius, in The Life of St. John Chrysostom, specifically mentions physicians working in a hospital built by the saint (PALLADIUS, Life of St. Jo. Chr., 45-46), while he does not do so in the case of a monastery in Nitria, in which a hospital for the travelling sick was built. (PALLADIUS, Lie of St. Jo. Chr., 149) Although this is only weak evidence that physicians were uncommon enough to deserve mentioning whenever they existed, it seems to be a more plausible position than assuming that they were ubiquitous to this kind of institution. This assumption of a universal presence of medical doctors is bound to be shaped by our current understanding of what a hospital is and how it works.

A second argument against our case is particularly aimed at the initial part of the current section. Quantification of written pieces of evidence often tends to ignore their qualitative aspect, which in this case includes the context in which institutions of care were mentioned. An example is the work of Procopius of Caesarea. It is common for him, in The Buildings of Justinian, to simply list institutions that were rebuilt by Justinian, and it is to be expected that in this case no physicians would be mentioned. We hope that our qualitative analysis of particular pieces of evidence linking medicine to the monastic tradition is enough to dispel doubt as to the conclusions taken from table 1 . Nonetheless, we 
admit that even if ours is a strong case for doubting some modern interpretations on the subject, it is still a weak case in establishing a position of our own - we can only state that if physicians did work in some of these institutions, this was certainly not the case for the majority of them.

A caveat with our analysis of written pieces of evidence is that this is a biased sample, for it only includes sources to which there are English or French translations. Apart from Portuguese, these are the only languages we are confident enough to use in an academic work. This means both that we were not able to use untranslated sources and that sources only translated to other languages were unavailable to us. ${ }^{6}$ On the other hand, secondary works often mention some of these pieces of evidence to which we had no access. From these secondary works we could gather that our case still stands: there is evidence of medicalization in only some Christian institutions, and no direct link between them and Hippocratic medicine. To further extend our analysis, we will now turn to archaeology.

\section{What archaeology tells us}

It must be emphasized that not all archaeological reports used by authors in this academic field were of easy access, and that the one analysed below was the only one that could be accessed online and that had useful information. ${ }^{7}$ New conclusions based on this corpus of evidence will necessarily have shaky foundations. Nevertheless, we think that this study was enough to outline a better critical understanding of the current interpretations regarding the functioning of ancient institutions of care, particularly regarding their functioning and the kind of medicine practiced in them.

\section{The Monastery of Apa Jeremias}

In the beginning of the $20^{\text {th }}$ century a big archaeological project was conducted in Saqqara, close to the Step Pyramid, in which a monastery probably built in the end of the $5^{\text {th }}$ century attributed to Saint Jeremias was found. This series of excavations generated many reports, one of which is of particular importance for our Scientific Initiation, for it shows a possible infirmary in the monastery. According to Andrew Crislip, this is the only piece of monastic evidence that tells us the size of infirmaries in those times. (CRISLIP, 2005, 11)

Because of this and other important characteristics of the site, Crislip uses the monastery of Apa Jeremias as part of the bedrock in which his arguments are based, in particular when he states that coenobitic monasteries had separate infirmaries dedicated to sick monastics, and in which medical doctors worked. (CRISLIP, 2005, 11-12) Because this archaeological report is of paramount importance to Crislip's theories as to the functioning of ancient hospitals, we found it important to read this report and check his conclusions. Below we can find a scheme of the constructions found at the monastery.

Figure 1 - General plan of the monastery
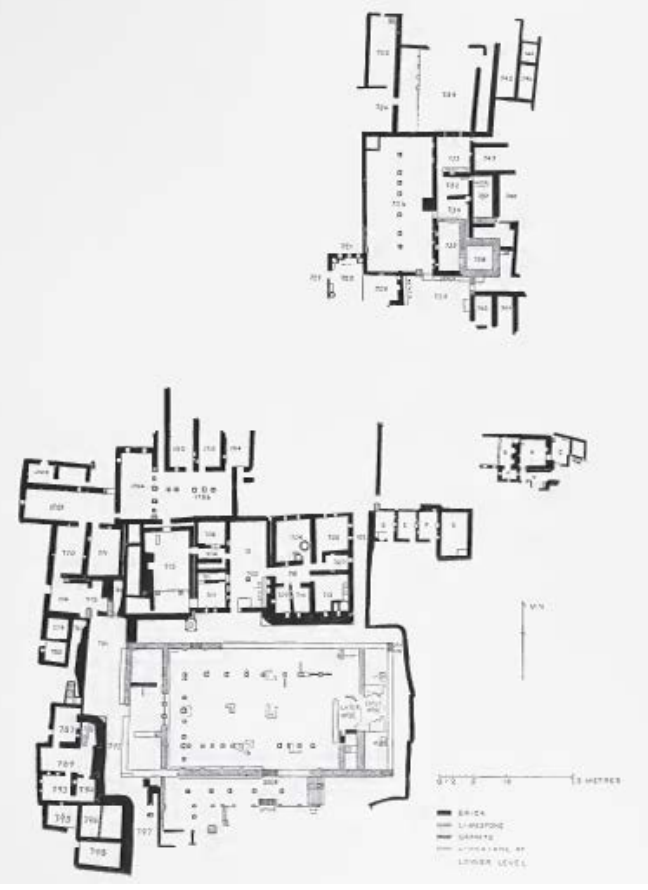

Source: QUIBELL, 1909, plate I

\footnotetext{
6 A good example is the work of Cyril of Scythopolis, to which we have found a German translation by Eduard Schwartz but no English French, or Portuguese translation.

7 Other reports that were of less or no use include Tsafrir and Foerster's report on excavations at Scythopolis that pertain to the period from the $4^{\text {th }}$ to the $7^{\text {th }}$ centuries, and an article by Cormack on the mosaic decoration of the church of St. Demetrios at Thessaloniki, believed to have been home of a xenodochia.
} 
As can be seen, the monastery divided into two main complexes of buildings, one to the south, and another to the northeast. We believe that the infirmary of this monastery was located in the section to the northeast, and specifically that it was room 726, the biggest room in this part of the complex. In the images below these can be seen separately, with a better resolution.

Figure 2 - Main part of the monastery

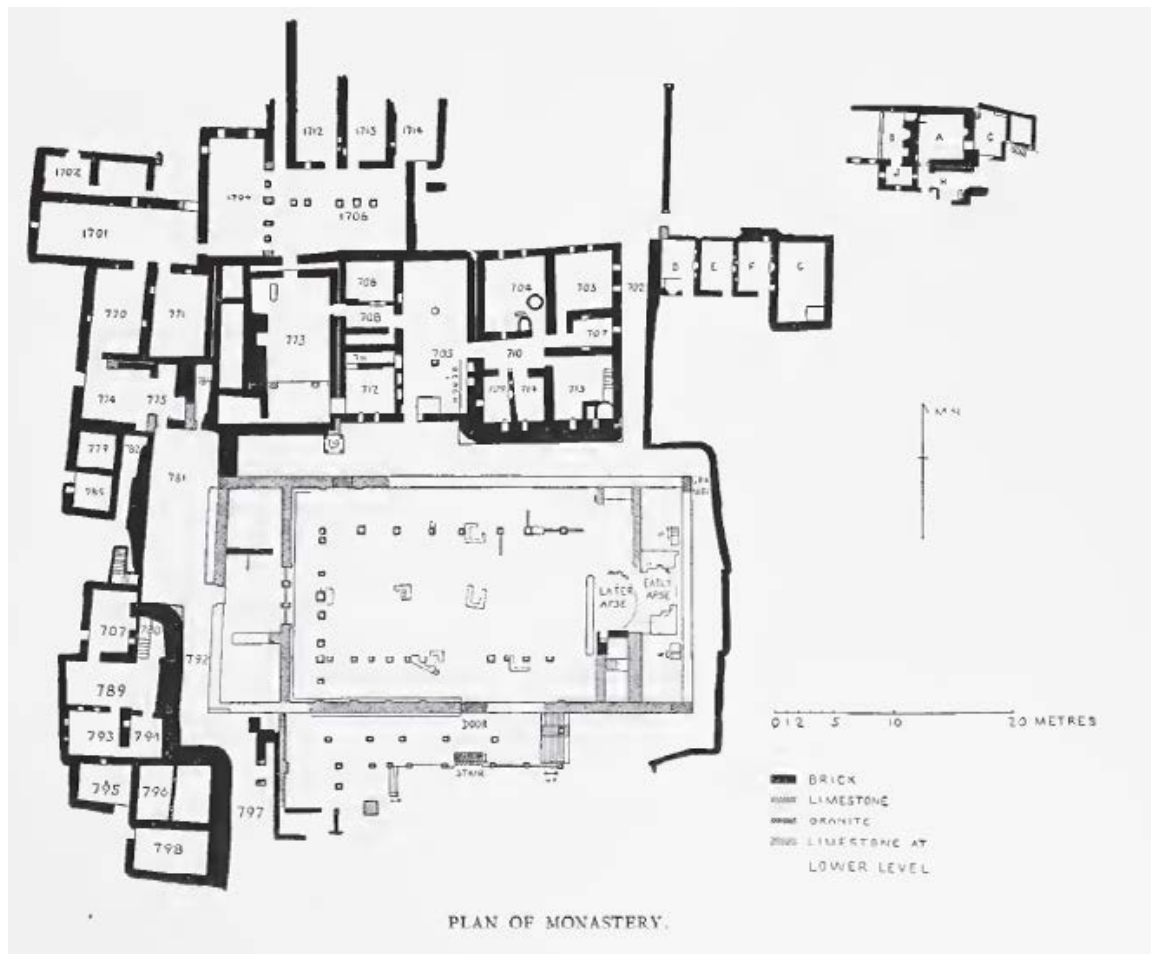

Source: QUIBELL, 1909, plate I

Figure 3 - Northeast section of the monastery

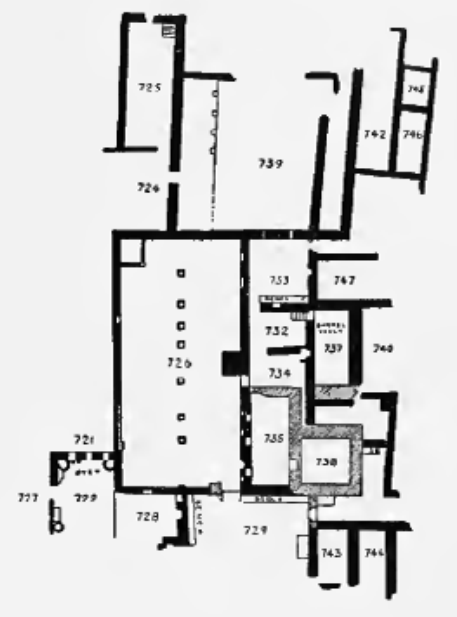

Source: QUIBELL, 1909, plate I

The first point to be emphasized is that the grounds for claiming that the structure found was an infirmary are weakly based on the evidence. No objects found in the room were clear indicatives of how it was used, and the only thing that points to an infirmary was an inscription in a limestone brick right beside one of its doors that said "My brother Apollo the son of my brother Abraham, the father of the infirmary, our brother Alex(ander), the attendant." (QUIBELL, 1909, 28 Therefore it is clear that there was an infirmary in the monastery, but it is not clear that room 726 is the correct one.

The report also mentions inscriptions that speak of medical treatment and explain how to apply certain medicines to certain wounds. These inscriptions were contained in room 700 $D$, which we believe is room D shown in Figure 2 . The instructions are shown in the image below. 
Figure 4 - Medical instructions as contained in the archaeological report

103. Black ink on plaster wall in room $7^{\circ}$ o D.

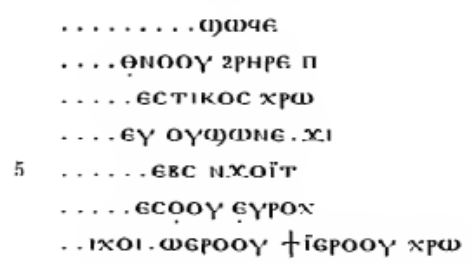

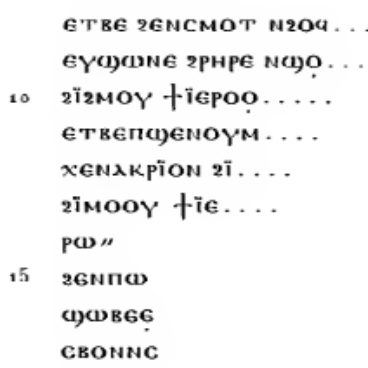

The columns are complete at top and bottom.

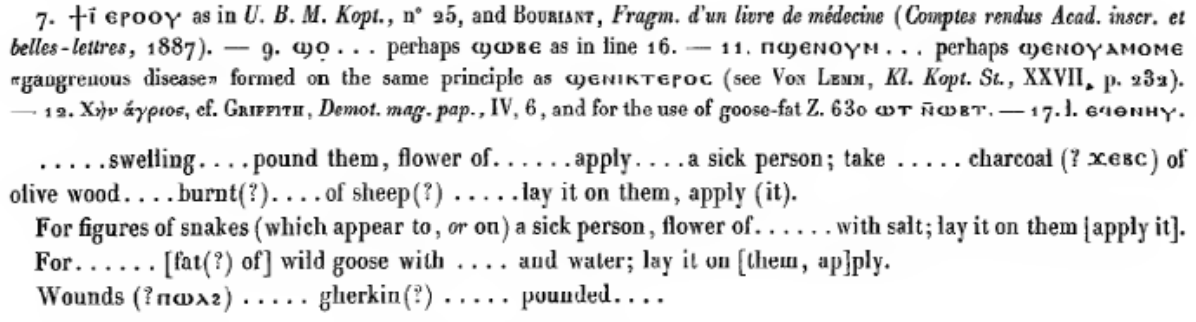

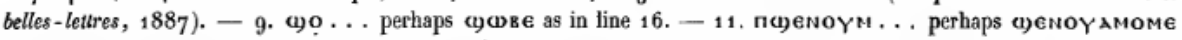
rgangrenous diseasen formed on the same principle as фуеліктерос (see Vox Lzm, Kl. Kopt. St., XXVII, p. 23з).

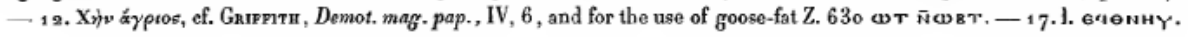

..... swelling. ... pound them, flower of. . . . apply . . . a sick person; take . . . charcoal (? $x \in \mathrm{BC})$ of olive wood. . . . burnt(?)... of sheep(?) .... . lay it on them, apply (it).

For figures of snakes (which appear to, or on) a sick person, flower of. . . . with salt; lay it on them [apply it]. For. .... [fat(?) of ] wild goose with .... and water; lay it on [them, ap]ply.

Wounds (?no>2) $\ldots$. gherkin(?) $\ldots$. . pounded....

This is an extract from a collection of medical prescriptions such as we have in Z. 629 .

Source: QUIBELL, 1909, 57

Two points are to be observed regarding this inscription. The first is that medical treatment as described in room $700 \mathrm{D}$ is clearly pragmatic. There is no mention of anything resembling the medical theories described in section II, including humors, dryness/wetness, and hotness/coldness of the body. There is mention only of kinds of wounds and of exactly what needs to be done to treat them.

The second point is that this inscription appears in the main section of the monastery, and not in the section that supposedly contained the infirmary. One possible interpretation is that room 726 is indeed the infirmary, but that not every sick person would be sent to it. Many of the sick monastics, especially those that had shallow skin wounds, such as the ones described in room $700 \mathrm{D}$, would be treated in the series of rooms in which this inscription was found. Only those with more severe illnesses, which required real medical attention and inpatient care, would go to the infirmary in which medical doctors would be ready to treat ailments with more sophisticated methods. Since nothing apart from the inscription in $700 \mathrm{D}$ mentions any kind of medical treatment, it is better to withhold judgment as to what kind of treatment was offered in this monastery.
Another interpretation is that room 726 was not the infirmary, which would have been located in rooms $700 \mathrm{D}, \mathrm{E}, \mathrm{F}$, and $\mathrm{G}$. This would mean not only that the infirmary was not so important a place in the monastery, if we take its size into consideration, but also that probably there were no medical doctors present to perform any kind of complex procedure such as surgeries. Medication would be done locally and by the monastics themselves, who would use the inscriptions in 700 $D$ as a guideline. This goes against what seems to have been common in other monasteries, as Crislip points out, for infirmaries were commonly placed separate to the main building of the monastery. (CRISLIP, 2005, 11-12) We withhold judgment as to which interpretation is most probable, for there is no parallel line of inquiry that refers to the monastery of Apa Jeremias and that could help us in this decision.

\section{Conclusion}

As is often the case with studies of Antiquity, and particularly so with Late Antiquity, there is little evidence from which to create generalizations. What we have tried to show is that the arguments some historians have recently proposed are at best 
weak in their empirical foundations, and at worst plainly speculative. For this, we have studied both written documents and the available archaeological reports on the matter. From the first set we have concluded that there is only an indirect link between Hippocratic medicine and Christian institutions of care, and this only in one instance of the written evidence. It is impossible to generalize, based on only one piece of written evidence, to three centuries and thousands of square kilometres.

From the archaeological evidence the case for the medicalisation of institutions of care is even grimmer, for we had access to only one piece of evidence. It did not make clear that doctors were an integral part of the monastic establishment, and worse still, it made clear that, if medicine was being applied, it as a completely pragmatic kind of medicine, with no relation to any complex theory of humors. It is therefore more similar to an Empiricist practice, to put it in terms of the medical sects described in section II.

Therefore, the presence of physicians in Christian institutions of care was not a given, and the assumption that physicians were a core part of the functioning of these institutions is, as has been previously stated, an undue generalization based on our current understanding of what hospitals are and how they work. It is clear by our written evidence that some of these institutions did have physicians working in them, but this evidence also tells us that probably these were a minority among philanthropic institutions. This means that, if they are to be credited with an important role in the dissemination of Christianity, this role must be based on their capacity for caring for the poor, via the donation of food and of a place where they could sleep, and not through their healthcare services to these same poor.

\section{Bibliography}

\section{Primary sources}

ATHANASIUS. Arian History. In: ATHANASIUS. Nicene and Post-Nicene Fathers of the Christian Church: Volume IV. Trans. by Archibald Robertson. Edinburgh: T\&T Clark, 1891. p. 270-302.

BASIL OF CAESAREA. The Long Rules. In: BASIL OF CAESAREA. The Fathers of the Church. A new translation. Volume 9. Trans. Monica Wagner. Washington: The Catholic University of America Press, 1962. p. 223-338.
CASSIODORUS. Institutiones. Translated by James W. and Barbara Halporn. Found in: http://faculty.georgetown.edu/jod/inst-trans.html. Access in: 20 Oct. 2018.

GREGORY OF NYSSA. On Virginity. In: GREGORY OF NYSSA. Nicene and Post-Nicene Fathers of the Christian Church: Volume V. Transl. by William Moore. Edinburgh: T \& T Clark, 1892. p. 342-371.

HIPPOCRATES. On the nature of man. In: HIPPOCRATES. Hippocrates: volume IV. Transl. by W. H. S. Jones. Cambridge, MA: Harvard University Press, 1959. p. 1-42. (Loeb Classical Library, 150).

HIPPOCRATES. Regimen in Health. In: HIPPOCRATES. Hippocrates: volume IV. Transl. by W. H. S. Jones. Cambridge, MA: Harvard University Press, 1959. p. 43-60. (Loeb Classical Library, 150).

JEROME. Letter LII, To Nepotian. In: JEROME. Nicene and Post-Nicene Fathers of the Christian Church. Volume VI. Transl. by W. H. Fremantle. Edinburgh: T\&T Clark, 1892. p. 89-96.

JEROME. Letter LIV, To Furia. In: JEROME. Nicene and Post-Nicene Fathers of the Christian Church: Volume VI. Transl. by W. H. Fremantle. Edinburgh: T\&T Clark, 1892. p. 102-109.

JEROME. Letter LXXVII, To Oceanus. In: JEROME. Nicene and Post-Nicene Fathers of the Christian Church: Volume VI. Transl. by W. H. Fremantle. Edinburgh: T\&T Clark, 1892. p. 157-163

JOHN OF EPHESUS. The Lives of the Eastern Saints. Trans. E. W. Brooks. In: JOHN OF EPHESUS. Patrologia Orientalis: Tomus decimus octavus. Paris: Firmin-Didot et Ca., 1924. p. 511-698.

ORIBASIUS. Oeuvres d'Oribase. Texte grec, en grande partie inédit, collationné sur les manuscrits. Transl. Ulco Cats and Charles Daremberg. Paris: Imprimerie nationale, 1851-1876.

PALLADIUS. The Dialogue of Palladius concerning the Life of St. John Chrysostom. Transl. Herbert Moore. London: The Macmillan Company, 1921.

PALLADIUS. The Lausiac History. Tranls. by W. K. Lowther Clarke. London: The Macmillan Company, 1918.

PLATO. Timaeus and Critias. Transl. by Robin Waterfield, with an introduction and noted by Andrew Gregory. Oxford: Oxford University Press, 2008. (Oxford World's Classics).

PLINY THE YOUNGER. Letters. Volume IV. Transl. by J. B. Firth. London: Walter Scott, 1900.

PLINY THE YOUNGER. Letters. Volume $X$. Transl. by J. B. Firth. London: Walter Scott, 1900

\section{Secondary sources}

ANDO, Clifford. Imperial Ideology and Provincial Loyalty in the Roman Empire. Berkeley: University of California Press, 2000. https://doi.org/10.1525/california/9780520220676.001.0001.

BROWN, Peter. Poverty and Leadership in the Later Roman Empire. Hanover and London: University press of New England, 2002. 
BROWN, Peter. Through the Eye of a Needle. Princeton: Princeton University Press, 2012.

CONSTANTELOS, Demetrios J. Byzantine Philanthropy and Social Welfare. New Brunswick: Rutgers University Press, 1968.

CRISLIP. Andrew. From Monastery to Hospital: Christian Monasticism \& the Transformation of Health Care in Late Antiquity. Ann Arbor: The University of Michigan Press, 2005. https://doi.org/10.3998/mpub.93465.

FERNGREN, Gary. Medicine \& Health Care in Early Christianity. Baltimore: The Johns Hopkins University Press, 2009.

HORDEN, Peregrine. The Earliest Hospitals in Byzantium, Western Europe, and Islam. The Journal of Interdisciplinary History, [s. l.], v. 35, n. 3, p. 361-389, Winter 2005. Poverty and Charity: Judaism, Christianity, and Islam. https://doi.org/10.1162/0022195052564243.

HORDEN, Peregrine. How Medicalised were Byzantine Hospitals? In: SOZIALGESCHICHTE Mittelalterlicher Hospitäler. Ostfildern: N. Bulst, K. - H. Spiess, 2007. p. 213-235.

JACKSON, Ralph. Doctors and Diseases in the Roman Empire. London: British Museum Publications, 1988.

JONES-LEWIS, Molly. Physicians and "Schools". In: IRBY, Georgia (ed.). A Companion to Science, Technology, and Medicine in Ancient Greece and Rome: Volume I. Oxford: Wiley Blackwell, 2016. p. 386-401. https://doi. org/10.1002/9781118373057.ch24.

LENDON, Jon. Empire of Honour. Oxford: Oxford University Press, 1997.

MILLER, Timothy S. The Birth of the Hospital in the Byzantine Empire. London: The Johns Hopkins University Press, 1997

NUTTON, Vivian. Ancient Medicine. New York: Routledge, 2004. https://doi.org/10.4324/9780203490914.

NUTTON, Vivian. Ancient Medicine. Second edition. New York: Routledge, 2013. https://doi. org/10.4324/9780203490914.

QUIBELL, J. E. Excavations at Saqqara, 1907-1908. Cairo: Imprimerie de L'Institut Français d'Archéologie Orientale, 1909.

ROCCA, Julius. Anatomy and Physiology. In: IRBY, Georgia (ed.). A Companion to Science, Technology, and Medicine in Ancient Greece and Rome: Volume I. Oxford: Wiley Blackwell, 2016. p. 345-359. https://doi. org/10.1002/9781118373057.ch21.

STARK, Rodney. The Rise of Christianity. How the obscure, marginal Jesus movement became the dominant religious force of the Western world in a few centuries. Princeton: Princeton University Press, 1996.

VEYNE, Paul. Bread and Circuses. Transl. by Brian Pearce with an introduction by Oswyn Murray. London: Penguin Books, 1990 [1976].

VOLTAGGIO, Michele. Xenodochia and Hospitia in Sixth-Century Jerusalem: Indicators for the Byzantine Pilgrimage to the Holy Places. Zeitschrift des Deutschen Palästina-Vereins, Is. L.J, Bd. 127, H. 2, p. 197-210, 2011.

\section{Júlio Matzenbacher Zampietro}

Graduando em História pela Universidade Estadual de Campinas UNICAMP

\section{Endereço para correspondência}

Júlio Matzenbacher Zampietro

Universidade Estadual de Campinas

Cidade Universitária Zeferino Vaz

Barão Geraldo, 13083-970

Campinas, SP, Brasil 